\title{
PROMOTING ETHICAL BEHAVIOUR IN THE EASTERN PARTNERSHIP COUNTRIES
}

\author{
Clara Volintiru, Associate Professor \\ International Business and Economics Department (REI) \\ The Bucharest University of Economic Studies (ASE) \\ Bucharest, Romania \\ clara.volintiru@rei.ase.ro \\ Mihai Volintiru, PhD Candidate \\ International Business and Economics Department (REI) \\ The Bucharest University of Economic Studies (ASE) \\ Bucharest, Romania \\ mihai.volintiru@gmail.com \\ Radu Mușetescu, Professor \\ International Business and Economics Department (REI) \\ The Bucharest University of Economic Studies (ASE) \\ Bucharest, Romania \\ radu.musetescu@rei.ase.ro
}

\begin{abstract}
The Eastern Partnership region is currently going through a process of institutional formation and consolidation in which promoting public ethics can play a major role in the legitimacy of its administration and attracting foreign investors. Through various datasets, we explore here the level of corruption in the region, as well as the measures that could be employed to counter it. The first section aims at assembling the conceptual references of corruption. Secondly, the analysis turns to the manifestation forms and the assessment of the extent of the phenomenon. Finally, this paper looks at the potential remedies. In this section,
\end{abstract}


the paper also deals with some of the anti-corruption approaches, as we assess preventive and corrective measures, and discuss the potential contribution of adopting international benchmarks of ethical behaviour in the public sector, such as the ISO 37001 Anti-bribery Management Systems.

\section{Keywords}

Corruption, Eastern Partnership, Ethics, Foreign Direct Investments, ISO 37001

\section{INTRODUCTION}

This article addresses the vulnerabilities faced by public authorities in Eastern Partnership (EaP) countries. We aimed to disentangle the propensity of certain forms of corruption (e.g. favouritism in public procurement, conflict of interests) from those that concern the public most (e.g. nepotism in appointing public officials, abuse of power in public office). In other words, the extent to which certain forms of corruption distort the activity of public authorities in EaP countries is not perfectly mirrored by popular concerns. This is to be expected, as citizens are often more inclined to sanction deficits of public service delivery or accessibility, as opposed to proprietary public procurement.

The hypothesis from which we start our research is that the more institutionalised the public administration is, in new democracies, the less pervasive the incidence of corruption is. For this purpose, we adopt an overall comparative assessment of all Eastern Partnership countries, but we focus in depth on benchmark cases of good or bad practices in specific instances. We assume that the more informal exchanges become institutionalised, the harder it is to uphold a non-discriminative bureaucratic system in place. The Eastern Partnership countries offer a good area of investigation, given that they present both similarity of context (i.e. post-soviet transition), as well as heterogeneity of current choice, with some of the EaP countries being more engaged in structural reform programs (i.e. Association Agreement countries-Moldova, Ukraine and 
Georgia), as opposed to others. However, our evidence is mixed in terms of the results of structural reforms.

The second analytical dimension of this study is to assess quantitatively and qualitatively the incidence of corruption in Eastern Partnership countries. The quantitative analysis reveals that, the lack of transparency is the main vulnerability in all case studies. Corruption generally has a negative impact on international investments. We look at the level of foreign direct investment in the Eastern Partnership countries to illustrate the economic dimension that could benefit most from the introduction of international standards of ethical conduct, such as the ISO 37001.

Finally, we looked at the institutional capacity to engage preventive and corrective measures of corruption. We estimate a limited affordability and availability of anti-corruption measures in the analysed countries, but a good competence and willingness to engage on the part of the public sector and civil society (only for preventive measures). For most case studies the same limitations and capacities can be observed. However, Georgia stands out as the most willing to engage in anti-corruption efforts, while Azerbaijan has the lowest competence to engage in preventive anti-corruption measures. Across all cases, the main method recommended to fight corruption is the increase of transparency and public awareness.

\section{CONCEPTUAL FRAMEWORK FOR THE ASSESSMENT OF CORRUPTION}

\subsection{Differentiating the layers of corruption}

The first step in an analysis of corruption is to properly define the term. The simplest definition of corruption is as a relationship in which services are exchanged for financial benefits - usually referred to as bribes. But, in reality, the phenomenon is more complex, as sometimes it is by abstaining to do something that public officials serve their informal clients. Other times, the service provided 
falls well within the job's prescriptions, but the manner in which it is delivered is the basis of the bribe - in an expedite form, or by delaying a certain procedure so as to favour somebody. Thus, often it is relatively hard to pinpoint the service that is being rendered in exchange for financial gains. Reversely, while petty corruption usually involves a monetary compensation for preferential services rendered, the more complex, high-ranking, grand corruption schemes usually involve more diverse forms of compensation.

These different layers and forms of corruption are usually included in the international organization's definitions of corruption: "the abuse of public office for private gain" (World Bank), "the abuse of entrusted power for private gains" (Transparency International), or "active or passive misuse of powers of public officials (appointed or elected) for private financial or other benefits" (OECD). Still, as encompassing as the definition of the phenomenon needs to be, as specific the legislation has to be. While the general conceptualization needs to be broad, the national legislative framework should narrow down on all of the possible angles of corruption, so that they are swiftly and efficiently prosecuted. Corruption is a phenomenon that received increasing attention from international agencies, governmental bodies, NGOs and academic institutions. It has been closely associated with bad institutional performance and as such, much consideration has been given to the ways to measure it (Kaufmann et al 2011). Nevertheless, no matter how much research is focused on this topic, most if its underpinnings remain elusive to the policy makers. Furthermore, while ample efforts have been deployed in the fight against corruption worldwide, in some cases the effects are modest to say the least. The reason why so many anticorruption policies fail is that they disregard the linkage specificities on the ground (Persson et al 2013, Johnston 2017, Mungiu-Pippidi and Johnston 2017). This paper does not support the deterministic view that certain cultures are more inclined to corruption than other. It does however encourage tailor-made anticorruption policies. In order to properly address informal linkage mechanisms that formed through innumerable exchanges, one must firstly understand the logic behind such interactions. Each setting, through its specific circumstances, provides different incentives for corruption. And it is these incentives that must be battled through institutional and policy efforts. A series of studies have 
shown for the post-soviet space the extent to which the norms and institutional setting inherited from the old regime has impacted the current party systems (Birch 1997, March 2006, Matsuzato 2006, Singer 2009).

For many citizens, in many countries, corruption provides an easier, more natural interaction with public officials than the formal channels do. It is not necessarily a cultural preference, as some studies have suggested (Miller et al 2001, Sandholtz and Taagepera 2005), but rather a customary preference. Due to multiple repetitions of such exchanges, it is institutionalized as the norm. Iterative relationships develop between different actors of the society, and representatives of public institutions, based on informal norms. Also, it gains ground, because sometimes bribing is more efficient in solving a citizen's problems, than the official process. This is mostly due to institutional deficiencies, such as oversized bureaucracy, and sinuous procedures.

This phenomenon needs not only targeted measures to fit each country's specific circumstances, but also sector-targeted measures. While corruption is a general problem, certain policy sectors have a higher risk (and higher stakes). For example, the public administration corruption often involves more pervasive schemes of embezzling than other fields. Furthermore, the institutional level is also a factor of differentiation in the phenomenon of corruption: the higher up the institutional scale, the more likely, a civil servant is to commit more complicated and damaging offensive, than low level bureaucrats. While the latter is often liable for receiving bribes, the first is usually more preoccupied with influence peddling.

Furthermore, most of the empirical evidence on corruption, whether it comes from the academic sphere, or the national anti-corruption institutions, covers single instances of corruption. As such, the aspect of "systemic corruption" embedded in the majority of institutional procedures, as a result of organizational failures, is misrepresented in the evidence. It is this systemic dimension of corruption that goes hand in hand with other informal practices such as clientelism, or patronage. Corruption is therefore a phenomenon that may be synchronized with clientelism, but it is not the same, as it does not involve political goals. It is still useful to consider it as a means of fuelling clientelistic networks within the political parties, and more broadly, the 
electorate. In the same sense, corruption is a means to reinforce patronage networks. If a public office is expected to offer great spoils, then the incentive to use patronage networks or electoral clientelism to obtain that position is greater. Inversely, if no other benefit than the official remuneration is expected to be obtained from a certain employment, much less investment will be made in the participation to a patronage network that can guarantee that job.

A significant stream of the existing literature discusses the impact clientelism might have on the clients' quality of life, in delivering public goods, and public policy that they might not otherwise be able to receive (Kawata 2006, Stokes et al 2013). As such, we find the channelling function of clientelism, not only as a discretionary distribution of public goods from the patron to the clients, but also as a means of communicating needs and grievances. As mentioned before, this is especially true in the context of poor institutional performance. It explains why informal and discretionary practices are embraced by society, often to a larger extend than the formal bureaucratic or political channels available to them. It is by fulfilling the brokerage between the state and society that clientelistic exchanges help stabilize cartel parties.

When public institutions fail to deliver efficiently and effectively public policy, and public goods, clientelism can be a good substitute to ensure the representation of popular interests, at the political and administrative level. This is especially focused on the benefits of clientelism as a mediator for receiving dedicated policy and public goods.

\subsection{Differentiating the consequences of corruption}

Corruption affects different dimensions of a public life: economic, social, and political. On each of these layers, widespread corruption has pervasive, longlasting consequences. A short inventory of these effects is useful to understand that corruption is more than a simple side gain, but an alteration of societal, economic or political functions. With informal exchanges, the linkages within a society are distorted, and the resulting systemic damages are far greater than the mere monetary amount of the bribes, or the initial gains of the corrupt interactions. 
The first, and most obvious implications of corruption are found along the economic dimension. The immediate effect is the wastefulness of state resources through the misuse of official powers for private gains. Thus, directly, or indirectly, public funds are being directed away from the public benefit. While petty corruption may significantly restrict the public goods delivered by public institutions, it does not have the biggest economic impact in comparison to grand corruption. It is through schemes of grand corruption involving public procurement, rigged contracts, or privatizations, that the most substantial part of the state resources is being channelled to serve private interests.

These latter manifestations of corruption have been especially prolific in the post-communist states. Two simultaneous circumstances have been creating the incentives for state exploitation: the public resources were vast -an inheritance from the planned economy model of the previous regime, and the reform process, including privatization of state assets, had to be done in a precipitated manner. Thus, although not a sufficient explanation for the extent of corruption, the transitional circumstances have created a propitious setting for the exploitation of state resources in a discretionary manner.

As opposed to petty corruption, the schemes involving large state assets are assembled through multiple parties - ranging from public officials, to national and international economic agents. Nevertheless, on both accounts, there is an implicit effect on the economy as a whole. When the public institutions are perceived to be corrupt, it usually serves as a disincentive to economic agents. Whether it is concerning the bureaucratic level, in necessitating bribes for any certification, or at the governmental level, in necessitating commissions to be paid to state officials for public contracts, systemic corruption is pervasive for the economic activity. It distorts natural market equilibriums, creating undue advantages for those actors that choose to comply with the exploitative schemes. The social dimension sums up the second category of consequences. The general theory of institutions is that they constrain people's corrupt behaviour, through formal, as well as informal rules and procedures. In turn, given the proper incentives, people often push back, by challenging the rules and procedures. When corruption becomes systemic, it occurs in a repetitive manner, which in turn institutionalizes such practices. Thus, through iteration, informal linkages 
become informal institutions, but institutions nonetheless, thus reinforcing and further consolidating the widespread practice of corruption. Figure 1 shows the process through which corruption is socialized, and becomes embedded in the reference system of accepted behaviour. This institutional adaptation as a result of iterative exchanges is equally applicable to other informal linkages besides corruption, such as clientelism (Hopkin Volintiru 2012, Gherghina and Volintiru 2017), or patronage (Kopecky et al 2012, Volintiru 2015).

\section{Contest/Challenge}

\section{BEHAVIOUR}

Corrupt linkages
INSTITUTIONS

Formal and Informal

Rules and Procedures

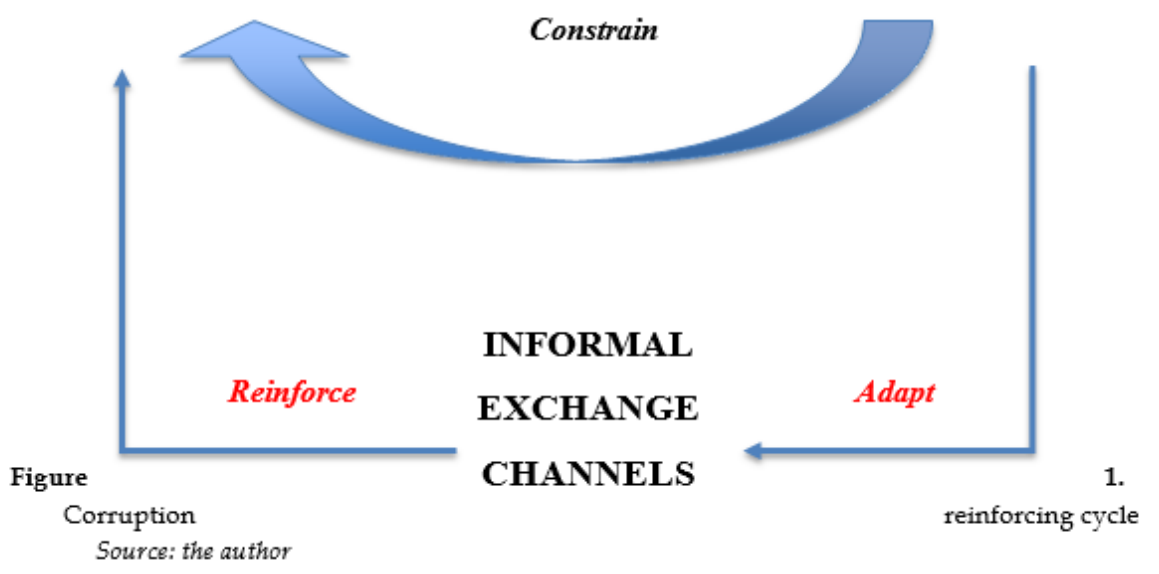

Figure 1. Corruption reinforcing cycle Source: the author

The social implications of the institutionalization of corruption are first and foremost the loss of trust in public institutions and the loss of trust in the political system. When representatives, whether appointed or elected, seize to serve the 
popular interest, they lose credibility. If the corruption phenomenon were limited in spread, this would be a problem for those representatives. But, when the corruption phenomenon is wide spread, systemic, embedded in every function of the public institutions, then the society redraws its trust in the system as a whole. The main problem is that once this happens, even if the anticorruption efforts yield results, it will take some time until people will start trusting the formal procedures again. In exchange, they usually take the route of informal linkages, as these are proved to be more efficient (see Fig 1). This creates on one hand, the opportunity of further proprietary exploitation within the institutional system, with no accountability pressure exerted by the disenchanted electorate, marked by apathy and disillusionment. On the other hand, the informal practice of corruption is reinforced, as citizens willingly resort to it, given its institutionalization.

Finally, it is also the political dimension that incurs repercussions of the incidence of corruption. As in all three cases, the more widespread the corruption phenomenon is, the more profound its consequences are to the broader societal relations and processes. In the political sphere, corruption bears immediate effects in the case of scandals affecting the credibility of certain politicians and political parties. By revealing the occurrence of illegitimate activity, a shadow is cast not only on the persons directly involved (i.e. public officials, civil servants, public works contractors etc.), but also on the governing structures that allowed for it to happen. Sometimes, for the public opinion to regain confidence in a ruling party, it is sufficient for certain persons to be publicly punished, but other times, the indignation is so great, that the whole party will be considered accountable for the spread of corruption. And while it is often isolated incidents that get extensive media coverage, the overall mechanism of attributing responsibility for the corrupt phenomena to those in power is fully congruent with the accountability relations of the electoral system. Still, as mentioned in the section on the social consequences of corruption, these accountability mechanisms lose purpose when the whole political class is seen as responsible for the incidence of corruption. Even if this is true, and inter-party collusion plays a role in protecting exploitative networks, the nature of the democratic system still requires a certain amount of trust to be placed by the 
citizens in their representatives, through the electoral selection process. When this trust is dangerously low, the result is the creation and development of parallel electoral systems (PES) (Volintiru 2012), through which votes are being purchased in clientelistic exchanges. Such a political selection system only consolidates the path toward corruption, making it part of the implicit relationship with the electorate.

In sum, corruption has an impact on the political dimension, both in terms of the electoral process, as well as in terms of the governmental function of governing parties. Electorally, high-level corruption consolidates the motivation to distort the electoral process, through such informal mechanisms as vote-buying, in order to ensure control of offices, and implicitly control of resources. Additionally, in this latter position of incumbency, institutional distortions occur, by changing the manner in which citizens relate to their representatives, be they elected or appointed. Both the citizens and the politicians that take part in parallel electoral systems (i.e. accept/offer personal benefits in exchange for political support) forgo the formal accountability relationship in favour of informal linkages, highly conducive and propitious for corrupt activities.

\section{PROMOTING PUBLIC ETHICS IN EASTERN PARTNERSHIP COUNTRIES}

\subsection{Current challenges in the Eastern Partnership in countering corruption}

In order to assess the extent of the corruption-related problems that the Eastern Partnership countries are currently facing, we use the Varieties of Democracy dataset to compare the levels of corruption in the executive, public sector, legislative and judiciary sectors across the post-soviet period. We find that in the case of some countries, ethical conduct (taken to be the absence of corruption) has improved over the period drastically, such as the case of Georgia. For other countries, such as Ukraine, or Moldova, there have been improvements over certain years, and moderate fall-backs in the recent years. Belarus scores 
relatively well in most corruption rankings of the region, due to the crack-down on corruption from its authoritarian regime.

The directionality of the Varieties of Democracy corruption indexes is from less corrupt to more corrupt. As such, in the case of the Executive corruption index (see Figure 2) and the Public sector corruption index (see Figure 3), the higher the annual value of the index, the higher the prevalence of corruption is.

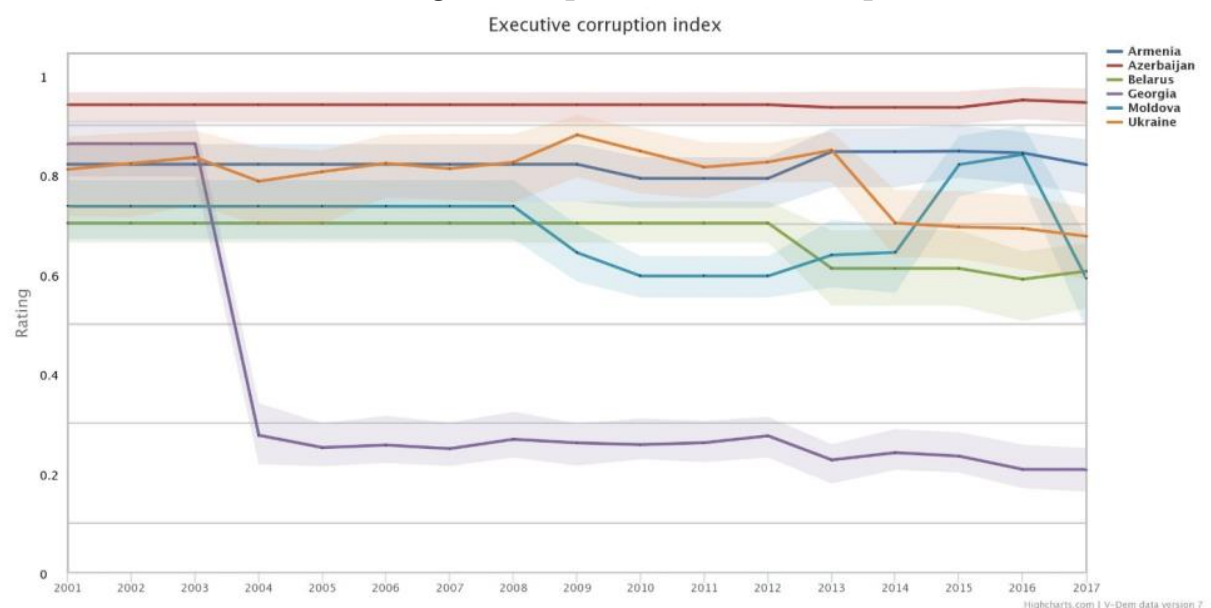

Figure 2. Executive corruption index in Eastern Partnership countries (20012016)

Source: Coppedge, M. et al 2018. "V-Dem [Country-Year/Country-Date] Dataset v8" Varieties of Democracy (V-Dem) Project. 


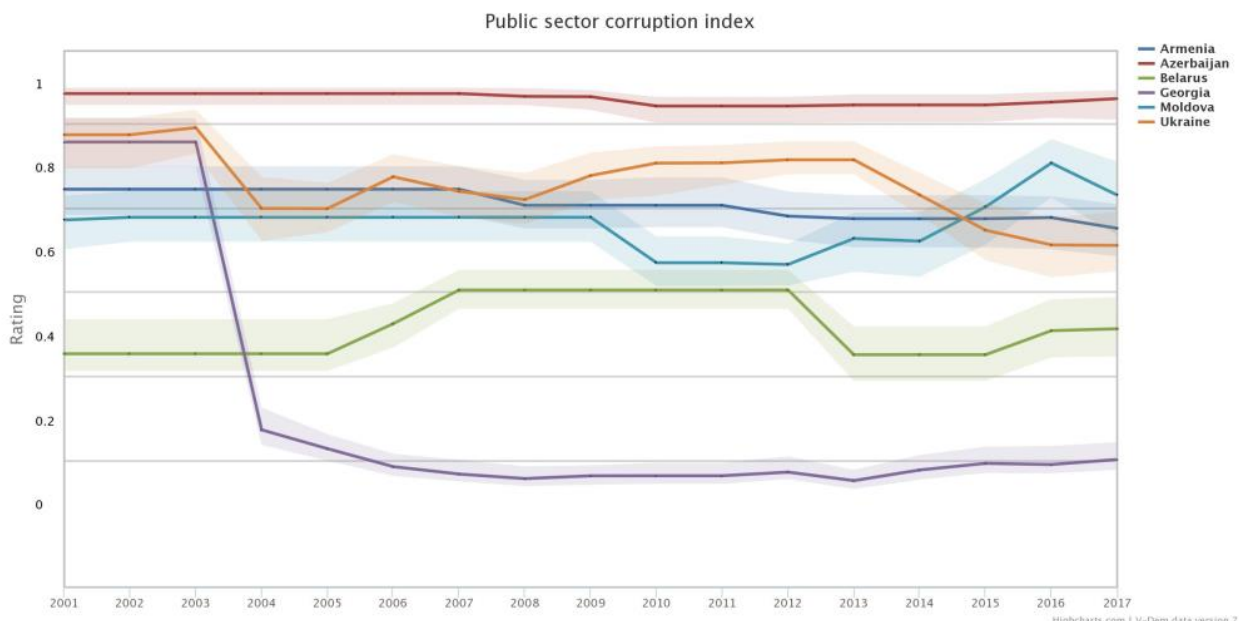

Figure 3. Public sector corruption index in Eastern Partnership countries (2001-2016)

Source: Coppedge, M. et al 2018. "V-Dem [Country-Year/Country-Date] Dataset v8" Varieties of Democracy (V-Dem) Project.

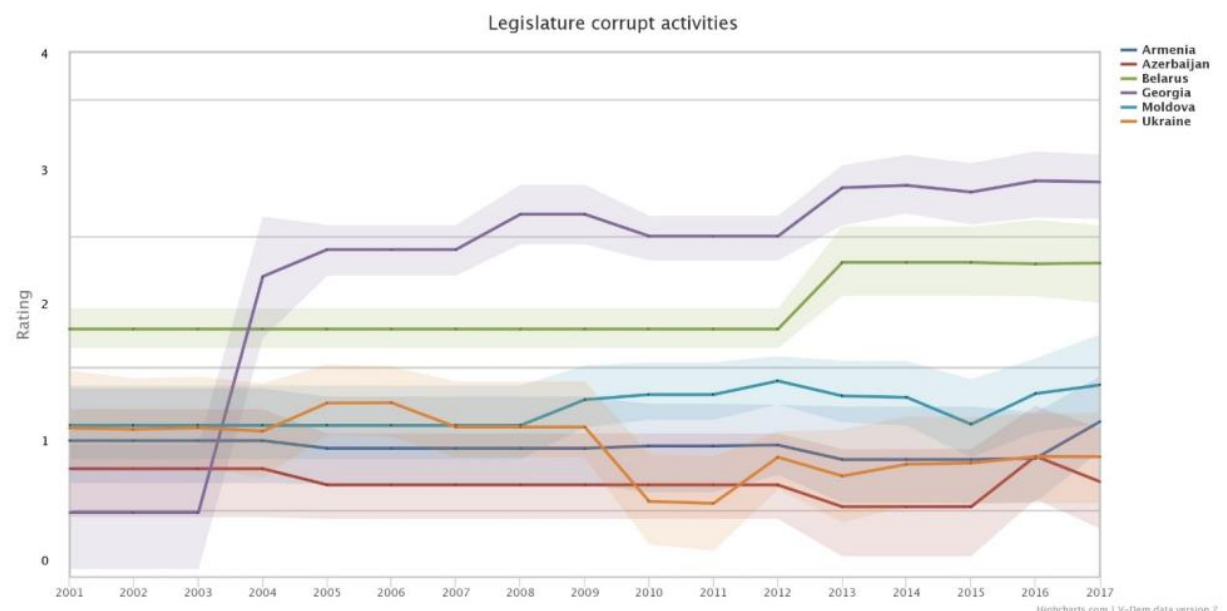

Figure 4. Index of legislature corrupt activities in Eastern Partnership countries (2001-2016) 
Source: Coppedge, M. et al 2018. "V-Dem [Country-Year/Country-Date] Dataset v8" Varieties of Democracy (V-Dem) Project.

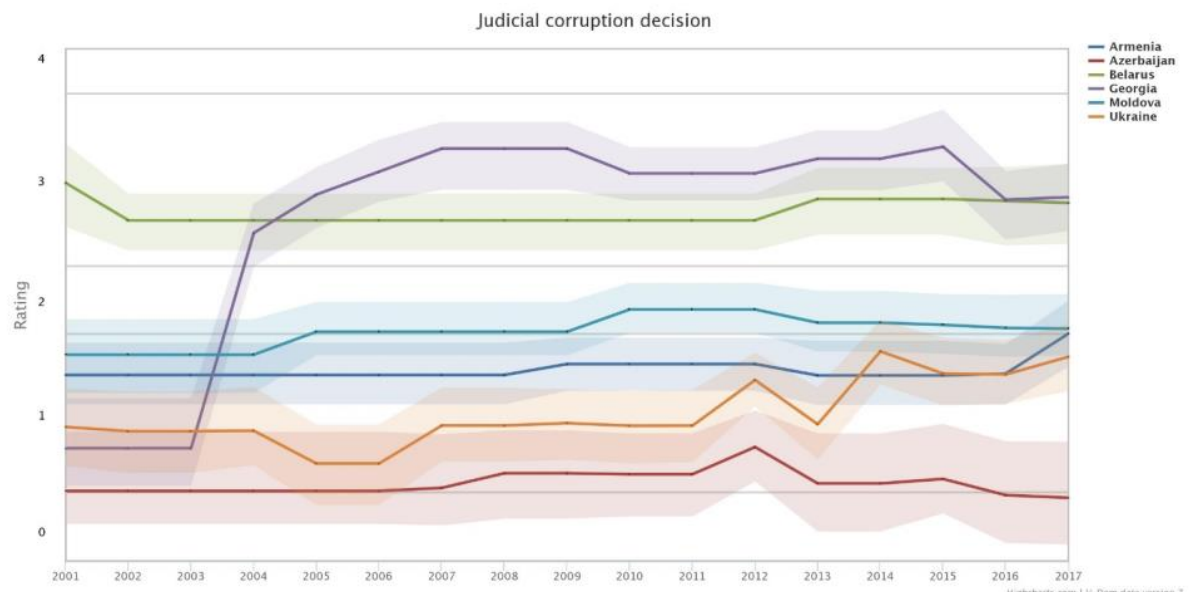

Figure 5. Index of judicial corrupt decisions in Eastern Partnership countries (2001-2016)

Source: Coppedge, M. et al 2018. "V-Dem [Country-Year/Country-Date] Dataset v8" Varieties of Democracy (V-Dem) Project.

In both the Executive and the Public sector corruption indexes, Georgia is outperforming the other countries in the region by far. In contrast, Azerbaijan is the worst performer in the region in terms of countering corruption, as it leads the ranking of the Eastern Partnership countries for the period 2001-2017.

Further, there are two are indexes in the Varieties of Democracy database that illustrate the situation in the Eastern Partnership countries with regards to both corruption aimed and influencing law making (see Figure 4) and that affecting implementation (see Figure 5).

According to Fish (2005) powerful legislatures can be instrumental to enhance accountability and reduce executive corruption, and that their role should be to limit, monitor and push back against the executive. Fish et al further argue that „executive corruption may be reduced if the legislature has the power and ability 
to investigate a majority of the executive's activities", as such oversight power "makes it more difficult for government officials to engage in corrupt practices" $(2015,2)$. They go on to test these hypotheses in cross-sectional, time series regression analysis covering virtually all countries from 2000 to 2010, and find that the power of legislatures to control their own budget and to pass legislation in practice is correlated with the reduction of corruption, and they also show how important it is for the legislatures to have actual powers of investigation and oversight over the executive, not just formal competencies (Fish et al 2015). In the Eastern Partnership countries, according to International Trade Centre data we can see that foreign direct investment (FDI) makes a significant contribution to the gross domestic product (GDP). The most spectacular contribution was made by foreign direct investment in Azerbaijan where, in 2003 and 2004, they accounted for more than half of the country's GDP. Their share subsequently declined to around $12 \%$ in 2016, but remains the country with the highest FDI contribution to GDP in the region. At the level of recent years, one of the main sources of FDI in Azerbaijan was Turkey, along with other European economies such as the Netherlands or the UK.

Although we do not have data for 2016, in the case of Georgia, we can also see from the International Trade Centre data a high level of foreign direct investment in GDP, with FDIs in Georgia accounting for $11.2 \%$ of its GDP in 2015. This marks a relative return to the 2008 levels of $12.4 \%$ of GDP. Before the economic crisis FDIs in this country represented as much as $18.5 \%$ in 2006 , and $15 \%$ the previous year.

The FDI levels as percentage of GDP show the contribution these can have in the economic development of the Eastern Partnership region. One of the ways to generate trust and attract foreign investors is to showcase a commitment to predictable and fair regulatory development and implementation. As such, efforts to counter corruption and promote public ethics can have a big impact on FDIs inflow. Shang-Jin Wei $(1999,2000)$ argued corruption has an adverse effect on growth by discouraging foreign direct investment and encouraging increased spending in government. Similarly, Mohsin Habib and Leon Zurawicki point to the negative impact corruption has on foreign direct investment, as "foreign investors generally avoid corruption because it is considered wrong and it can 
create operational inefficiencies" $(2002,1)$. Blackburn et al (2006) and Busse and Hefeker (2007) make similar claims.

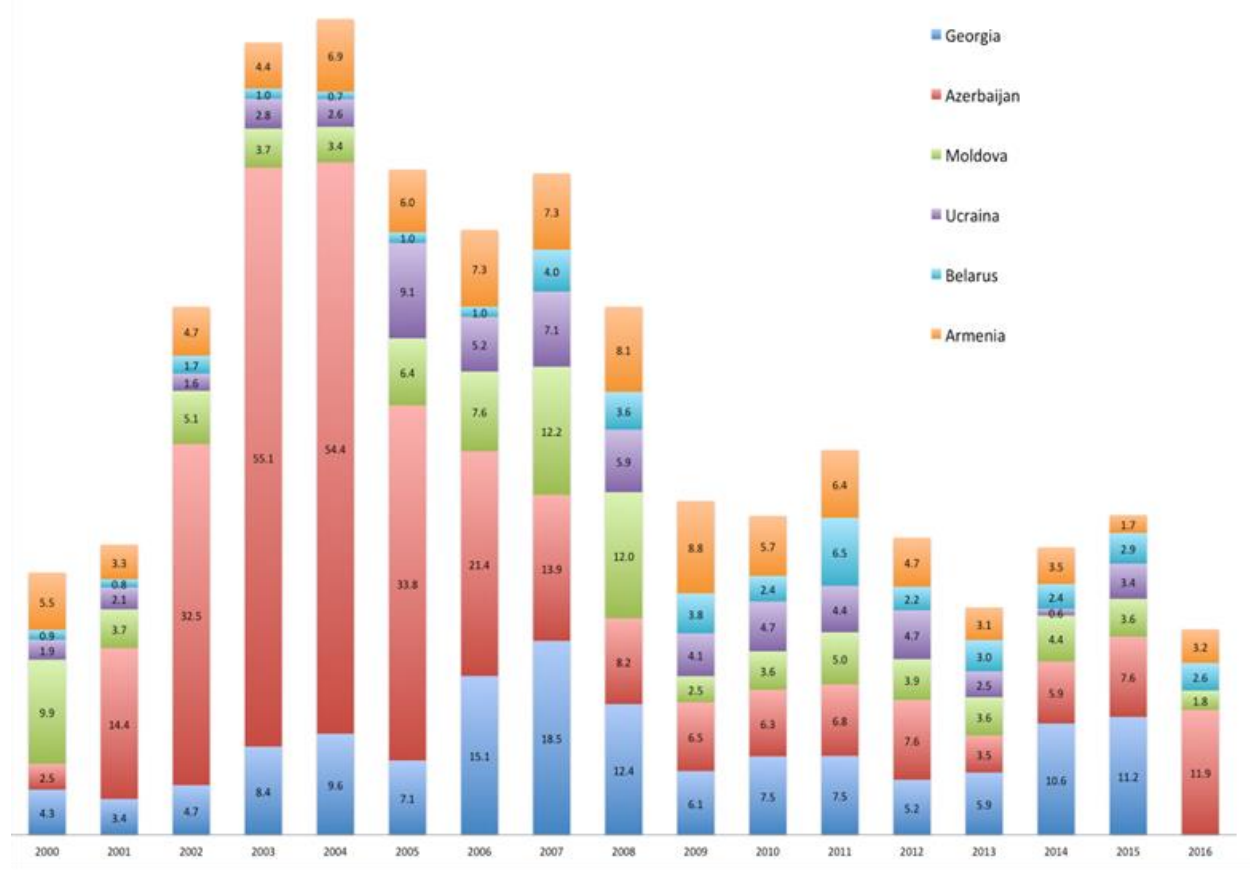

Figure 6. Foreign direct investments (FDI) in Eastern Partnership countries (2000-2016) (\%GDP)

Source: adapted by the authors from the International Trade Centre data

According to Brescia (2017, 1) "corruption strongly affects international companies with high investments and high revenues, influencing also the work of managers and decision-makers". That is also a very convincing argument due to the fact that World Bank assesses the fact that businesses and individuals pay an estimated $\$ 1.5$ trillion in bribes each year or $2 \%$ of global GDP, according to its Enterprise Surveys. 
3.2. Measures to promote ethical behaviour in Eastern Partnership countries

We have developed an institutional capacity assessment built on four levels of assessment: affordability, availability, competence, and willingness to engage (see for further details Volintiru et al 2017). The affordability layer is designed to reflect the extent to which local and regional authorities in each of the Eastern Partnership countries have the possibility to allocate material and human resources to designing and deploying anticorruption tools and tactics. The layer of availability refers to both access to international cooperation and training sessions on anticorruption, as well as local or grassroots initiatives to monitor the local and regional authorities (e.g. Go Local, Ukraine). Competence and willingness to engage are both dimensions of assessment of the human resource employed in local and regional authorities. We do not restrict the category of anticorruption agents to public sector employees, as important measures can be taken from outside the institutions (e.g. third party monitorization), but a longterm perspective on anticorruption efforts is fundamentally reliant on the integration of public ethics within the institutional process of the local and regional authorities.

We collected the relevant data on these anticorruption measures through an expert survey questionnaire applied in 2017 as part of a Committee of Regions research project (Volintiru et al 2017). We deployed an expert survey conducted in all Eastern Partnership (EaP) countries between 12 December 2016-20 January 2017. The survey was translated in all six national languages, and we have 126 respondents in total. The targeted category of respondents were: academics, public sector employees, politicians, journalists and representatives of local and international civil society organizations (CSO) (e.g. Freedom House, Open Society, Transparency International, German Marshall Fund), international organizations experts (e.g. NATO, OSCE, Council of Europe, GRECO, World Bank) and other senior local experts.

We applied this assessment framework for both preventive and corrective measures in the fight against corruption at the level of local and regional authorities. Preventive measures are here considered to be those that try to stop 
the occurrence of corruption beforehand (e.g. transparency of administrative procedures, rotation of personnel in positions at risk, codes of ethics/of conduct, mandatory declarations of personal interests). Corrective measures are here considered to be those that are deployed in an attempt to stop or punish corruption after it has occurred (e.g. whistleblowing, referral to appropriate regulatory agencies). The latter can also have confounding effects with preventive efforts as anticorruption campaigns can sometimes create deterrence effects. Nevertheless, for the purpose of the present study, we distinguish between the two as different institutional approaches to anticorruption efforts. Most Eastern Partnership countries seem to have limitations in affording to allocate resources to both preventive and corrective efforts. Surprisingly, for Azerbaijan we find the expert opinion to suggest that there is a limited capacity overall regarding preventive measures, although Azerbaijan holds one of the main best practices in terms of accessibility and transparency of public services via the online portal ASAN. The explanation for this apparent contradiction is that the integrated public services' portal is designed by an executive agency of the state (see above) with a much higher budget than a local or regional authority might afford allocating towards such measures.

In general, there are no big variations between the experts' assessment of preventive and corrective anti-corruption measures in their country. There is one noticeable exception: in Azerbaijan there is a much smaller evaluation of competence and willingness to engage in preventive anti-corruption measures as opposed to corrective ones. 


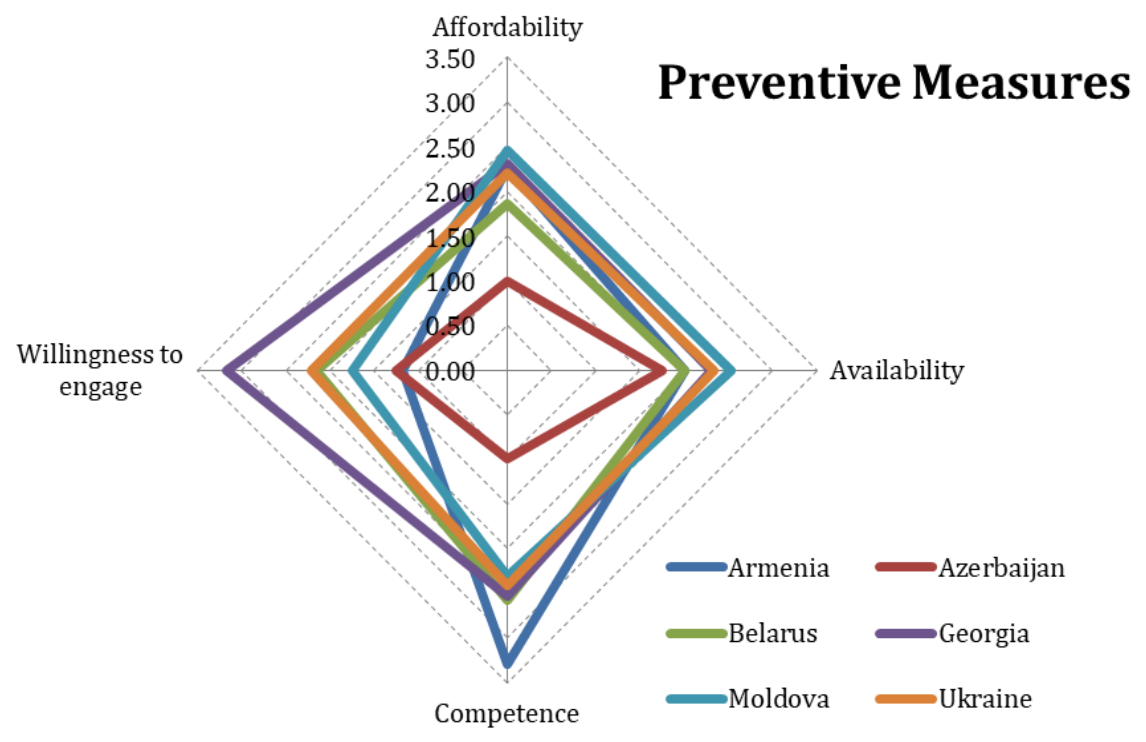

Figure 7. Institutional capacity in developing preventive anti-corruption measures

Source: Volintiru et al 2017

As we have seen above, Georgian experts have specifically chosen to refer to inadequate budgetary allocations for local and regional authorities and unqualified staff as main vulnerabilities in the provision of public services (see Table 1). Nevertheless, within the institutional capacity assessment, Georgia scores slightly above all other Eastern Partnership countries, as having a good institutional capacity especially in terms of willingness to engage and competence (surpassed here only by Armenia). Furthermore, Georgia seems to have a strong will to tackle corruption both in preventive and corrective measures. We can thus infer two things. On one hand, in the Corruption Perception Index (CPI), Georgia has the highest score (57) in the Eastern Partnership region-averaged at 30, which shows both a popular and an institutional commitment to fighting corruption. On the other hand, based on the qualitative analysis of corruption occurrences, the poor allocation of financial 
and human resources in public administration creates vulnerabilities for corruption in social service delivery, not in the overall public service system.

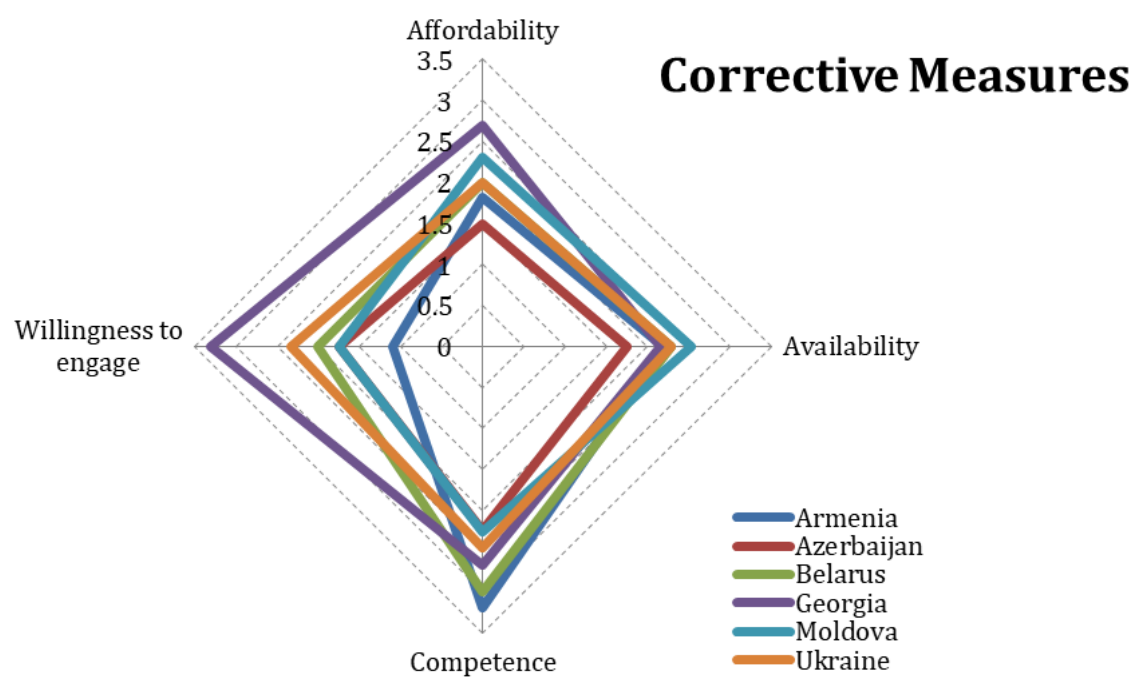

Figure 8. Institutional capacity in developing corrective anti-corruption measures

Source: Volintiru et al 2017

The key to understanding the inclination of decision-makers to implement any form of anti-corruption measures is to link them to any electoral capital these might bring them. Public ethics can be in general a positive attribute for any incumbent, but it is reliant on the public's awareness. In this sense, we can see the case of Belarus where preventive anticorruption measures are judged to have a limited capacity, while corrective ones have a good one-one of the highest in the region alongside Armenia. This can be explained by the fact that anticorruption campaigns have the dual goal of generating deterrence (or hierarchical obedience), while reassuring the public of the vigilance of relevant oversight bodies. In contrast, little is done to improve the quality or transparency of the public procurement system and public service delivery. 
When ranking together the institutional capacity assessment for all types of anticorruption measures based on the Eastern Partnership regional averages we find almost all of them to have a moderate capacity. Only the willingness to engage in preventive measures is below average, judged by experts to be limited. This is counterproductive, as preventive measures are some of the least costly (e.g. sharing best practices, increasing transparency and accountability). In the electoral gains light, they are however less noticeable as correcting already manifested problems. In this sense, as we will detail in the final section of this report, many of the efforts to counter corruption in Eastern Partnership countries have to increase the conceptualization of personal benefits to decision-makers in engaging in preventive anticorruption measures.

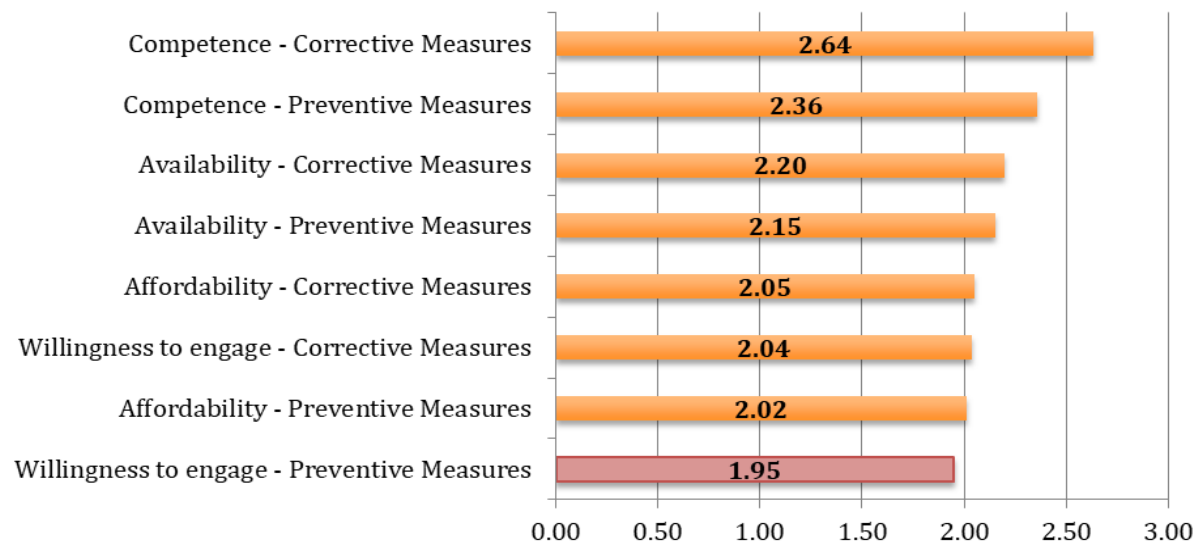

Figure 9. Comparative institutional capacity in anti-corruption measures across Eastern Partnership countries

Source: Volintiru et al 2017

Experts were also asked about the best methods to counter corruption at the level of public administrations. Table 1 includes the percentage of answers. Every respondent had could pick a maximum of three answers, including the opportunity to list separate measures under "other".

Regardless of country differences, the main method indicated by the experts is to increase transparency and public awareness about the activities of the local and 
regional administrations. This is intuitive when scrutinizing the answers about the forms of corruption. Favouritism, nepotism and abuse of power in public office emerged as relevant forms of corruption in almost all the investigated countries. The positive experiences of countries dealing with corruption in the past illustrate that the increase of transparency can effectively help in the fight against corruption.

The second major observation, when looking at the results included in Table 3, is that there is no single method preferred to counteract corruption, with the exception of increasing transparency, which is favoured by the majority of experts within a country. In other words, there is little agreement among experts about the impact of other methods. Some methods are generally considered to have less impact, such as information about the causes and consequences of corruption, employees' training on preventive measures or employees' instruction on corrective measures.

Table no 1 . The perception about the methods to counteract corruption in LRAs $(\%)$

\begin{tabular}{|c|c|c|c|c|c|c|}
\hline & Armenia & Azerbaijan & Belarus & Georgia & Moldova & Ukraine \\
\hline $\begin{array}{r}\text { Information } \\
\text { about its } \\
\text { causes and } \\
\text { consequences }\end{array}$ & 33 & 33 & 11 & 16 & 17 & 12 \\
\hline $\begin{array}{r}\text { Training on } \\
\text { preventive } \\
\text { measures }\end{array}$ & 8 & 17 & 33 & 28 & 22 & 20 \\
\hline $\begin{array}{r}\text { Instruction } \\
\text { about } \\
\text { corrective } \\
\text { measures }\end{array}$ & 25 & 17 & 22 & 50 & 22 & 24 \\
\hline $\begin{array}{r}\text { Raise } \\
\text { awareness } \\
\text { among citizens } \\
\text { and NGOs }\end{array}$ & 42 & 50 & 67 & 0 & 61 & 56 \\
\hline
\end{tabular}




\begin{tabular}{|c|c|c|c|c|c|c|}
\hline $\begin{array}{r}\text { Strengthen } \\
\text { administrative } \\
\text { capacity }\end{array}$ & 25 & 17 & 22 & 22 & 48 & 20 \\
\hline $\begin{array}{l}\text { Use external } \\
\text { expertise }\end{array}$ & 17 & 33 & 22 & 33 & 30 & 36 \\
\hline $\begin{array}{r}\text { Increase } \\
\text { transparency } \\
\text { and public } \\
\text { awareness on } \\
\text { activities }\end{array}$ & 92 & 83 & 89 & 89 & 91 & 72 \\
\hline Other & 25 & 33 & 11 & 22 & 9 & 32 \\
\hline
\end{tabular}

Source: Volintiru et al 2017

Other methods are seen as effective by a larger share of the experts. These include raising of awareness of citizens and NGOs (the second most relevant form to counteract corruption in Azerbaijan, Belarus, Moldova and Ukraine) or strengthening administrative capacity. This diversity of answers indicates that several methods may be employed to complement the increase in transparency to help in the fight against corruption.

Over half of country experts said that external consultants were employed by local public authorities in Moldova with the purpose of providing transparency to administrative activities and preventing the wasteful allocation of public resources. In Georgia, external experts are not usually employed, and the mentioned fields of expertise were the provision of public transportation, and the assessment of the illegal use of imprisonment.

Published in the fall of 2016, after two years of elaboration, ISO 37001 - Antibribery management systems establish guidelines for implementing, maintaining and improving a well-defined anti-bribery management system in companies worldwide. This system was developed in order to be applicable in any size organization. It can be integrated into the overall management system (ISO 9001) and it addresses only the issue of bribery in public, profit or non-profit organizations. In the context of the developing countries, the implementation of 
the ISO 37001 can create similar incentives to promote ethical behaviour and compliance as some of the previous well-known benchmarks as the Bribery Act (UK) and the Foreign Corrupt Practices Act (FCPA) (USA). As opposed to the compliance codes of conduct that are mainly focused on the private sector as suppliers of bribes, ISO 37001 is a novel alternative that focuses mainly on the public sector as the demand for bribes.

According to Manuhwa and Stansbury (2016) an organization that voluntarily decides to implement ISO 37001 is supposed to facilitate the development of policies and procedures designed to prevent bribery. The genuine commitment of the organization's top management to make the system work is mandatory in order to have an effective implementation of specific policies and procedures by the organization. Monitoring and review of the effectiveness of these policies and procedures is also a key point, as it is continual improvement of the policies and procedures in order to ensure their effectiveness.

Bribery incidence (measured as \% of firms experiencing at least one bribe payment request) according to World Bank puts Ukraine on top with 50.4\%, followed by the Republic of Moldova with 31\%, and Azerbaijan with 15,9\%. The other countries from the Eastern Partnership scored better with Belarus at $8.9 \%$, Armenia $7.1 \%$ and Georgia $2.2 \% .{ }^{1}$

Although having ISO 37001 implemented does not necessarily serve as a generic proof of good practice, it is a sign that the organization focuses on the prevention of corruption and that it maintains a framework that discourages illegal practices by preventing, detecting and responding vehemently to bribery and complying with anti-bribery laws. Prosecutors cannot in fact rely in any way on the existence of ISO standard 31007 when investigating illegal practices, but companies that have anti-bribery management systems implemented can find the documentation elaborated for the certification of the system helpful in providing evidence to sustain their case.

1 World Bank, Enterprise Surveys, available at: enterprisesurveys.org. 


\section{CONCLUSIONS}

This article has addressed the issue of corruption in the Eastern Partnership countries with an eye for potential countering measures and the implications of promoting public ethics. We developed a broad comparative assessment of the countries in the region, while focusing at the same time at specific benchmark examples from certain cases. As we showed here, there are several explanations that can be ascribed to the current levels of corruption in the region, as both transitional circumstances and current day incentives play a role. As some of the Eastern Partnership countries have become closer to the European Union than others (i.e. the signatories of the Association Agreement), we see in these cases a much more pronounced improvement on the corruption indexes, such as in the case of Georgia. We develop a more encompassing understanding of what corruption is and how it manifests itself, as we explore its social, economic and political dimensions, as well as its manifestation at the executive, legislative, or judiciary levels.

In the final section of this article, we use an original dataset to illustrate how preventive measures to fight corruption lag behind corrective ones. If we focus, as we argue we should, on the positive effects of promoting public ethics, and not just countering bad practices in the public sector, then a much higher emphasis should be ascribed to preventive efforts. Creating a positive normative loop in the public sector can yield extensive benefits, not only in the wellfunctioning of public institutions, but also, as we show here, in terms of economic growth and development by attracting foreign direct investments. We argue that the implementation of the newly developed international standard on Anti-bribery Management Systems (ISO 37001) could go a long way in promoting public ethics and enforcing trust amongst foreign investors and other domestic and international private sector partners.

Further research is needed to explore the extent to which public administrations in the Eastern Partnership countries have implemented any set of procedures to promote ethical behaviour and compliance. Such a systematic assessment of local practices would give us an in-depth look on good practices, and what can be done to further strengthen an ethical climate in the public sector in the region. 
Additional qualitative evidence on reform measures that proved to work in some of these countries can also broaden our understanding of how to scale up reform measures designed to enhance public ethics and counter corruption in the region.

\section{ACKNOWLEDGEMENT}

Some of the data presented here was previously collected in two research projects and we are indebted to our colleagues that informed and illuminated us on the region and the topic at hand: Sergiu Gherghina, Iordan Bărbulescu, Miruna Troncotă, Ellie Knott, and Mathieu Tromme.

\section{REFERENCES}

- Bărbulescu, Iordan, Volintiru, Clara, Troncotă, Miruna and Toderaș, Nicolae. 2017. „România - furnizor de expertiză în tranziție democratică pentru țările Parteneriatului Estic și Balcanii de Vest". IER SPOS Report. http://www.ier.ro/sites/default/files/pdf/SPOS\%202017_Studiul_2_FINA L.pdf

- Birch, Sarah.1997. "Nomenklatura democratization: Electoral clientelism in post-soviet Ukraine." Democratization 4, no. 4: 40-62.

- Blackburn, Keith, Niloy Bose, and M. Emranul Haque. 2006. "The incidence and persistence of corruption in economic development." Journal of Economic Dynamics and Control 30, no. 12: 2447-2467.

- Busse, Matthias, and Carsten Hefeker. 2007. "Political risk, institutions and foreign direct investment." European journal of political economy 23, no. 2: 397415.

- Coppedge, Michael, John Gerring, Carl Henrik Knutsen, Staffan I. Lindberg, Svend-Erik Skaaning, Jan Teorell, David Altman, Michael Bernhard, M. Steven Fish, Agnes Cornell, Sirianne Dahlum, Haakon Gjerløw, Adam Glynn, Allen Hicken, Joshua Krusell, Anna Lührmann, Kyle L. Marquardt, Kelly McMann, Valeriya Mechkova, Juraj Medzihorsky, Moa Olin, Pamela Paxton, Daniel Pemstein, Josefine Pernes, Johannes von Römer, Brigitte Seim, Rachel Sigman, Jeffrey Staton, Natalia Stepanova, Aksel Sundström, Eitan 
Tzelgov, Yi-ting Wang, Tore Wig, Steven Wilson, and Daniel Ziblatt. 2018. "V-Dem [Country-Year/Country-Date] Dataset v8". Varieties of Democracy (VDem) Project. https://doi.org/10.23696/vdemcy18

- Fish, M. Steven. 2006. "Stronger legislatures, stronger democracies." Journal of democracy 17, no. 1: 5-20.

- Fish, M. Steve, Katherine E. Michael and Staffan I. Lindberg. 2015. "Legislative Powers and Executive Corruption". Varieties of Democracy Institute, Working Paper (WP) 7.

- Gherghina, Sergiu, and Clara Volintiru. 2017. "A new model of clientelism: political parties, public resources, and private contributors." European political science review 9, no. 1: 115-137.

- Habib, Mohsin, and Leon Zurawicki. 2002. "Corruption and foreign direct investment." Journal of international business studies 33, no. 2: 291-307.

- Hopkin, Jonathan. 2006. "Conceptualizing political clientelism: Political exchange and democratic theory." In APSA annual meeting, Philadelphia, vol. 31, pp. 46-18.

- Johnston, Michael. 2017. Political corruption: Concepts and contexts. Routledge.

- Kaufmann, Daniel, Aart Kraay, and Massimo Mastruzzi. 2011. "The worldwide governance indicators: methodology and analytical issues." Hague Journal on the Rule of Law 3, no. 2: 220-246.

- Kawata, Jun'ichi, ed. 2006. Comparing political corruption and clientelism. Ashgate Publishing, Ltd.

- Manuhwa, Martin, and Neill Stansbury. 2016. "Anti-Bribery Standards, Systems and Strategies for Optimising Engineering Projects Delivery." Working Paper.

- March, Luke. 2006. "Power and opposition in the former Soviet Union: The communist parties of Moldova and Russia." Party Politics 12, no. 3: 341-365.

- Matsuzato, Kimitaka. 2006. "Differing Dynamics of Semipresidentialism across Euro/Eurasian Borders: Ukraine, Lithuania, Poland, Moldova, and Armenia." Demokratizatsiya 14, no. 3.

- Miller, William L., Ase B. Grodeland, and Tatyana Y. Koshechkina. 2001. "A culture of corruption." Coping with Government in Post-communist Europe: Central European University Press Budapest, Hungary.

- Mungiu-Pippidi, Alina, and Michael Johnston, eds. 2017. Transitions to Good Governance: Creating Virtuous Circles of Anti-corruption. Edward Elgar Publishing. 
- Persson, Anna, Bo Rothstein, and Jan Teorell. 2013. "Why anticorruption reforms fail-systemic corruption as a collective action problem." Governance 26, no. 3: 449-471.

- Sandholtz, Wayne, and Rein Taagepera. 2005. "Corruption, culture, and communism." International Review of Sociology 15, no. 1: 109-131.

- Singer, Matthew. 2009. "Buying voters with dirty money: The relationship between clientelism and corruption." Working Paper.

- Stokes, Susan C., Thad Dunning, Marcelo Nazareno, and Valeria Brusco. 2013. Brokers, voters, and clientelism: The puzzle of distributive politics. Cambridge University Press.

- Volintiru, Clara. 2012. "Clientelism: electoral forms and functions in the Romanian case study." Romanian Journal of Political Science 12, no. 1: 35.

- Volintiru, Clara. 2015. "The exploitative function of party patronage: does it serve the party's interest?." East European Politics 31, no. 1: 39-55.

- Volintiru, Clara, Gherghina, Sergiu, Knott, Ellie and Mușetescu, Radu. "Preventing Corruption and Promoting Public Ethics at the Local and Regional Level in Eastern Partnership Countries". 2017. Committee of the Regions Report http://www.lse.ac.uk/business-andconsultancy/consulting/assets/documents/preventing-corruption-andpromoting-public-ethics.pdf

- Volintiru, Clara, Trandafir, Gelu, Toma, Bianca, Nuțu, Otilia și Damian, Alex. 2018. „State-Owned Companies: Preventing Corruption, Clientelism and State Capture", National Report, http://www.crpe.ro/en/wpcontent/uploads/2018/01/Romania.pdf

- Wei, Shang-Jin. 1999. Corruption in economic development: Beneficial grease, minor annoyance, or major obstacle?. The World Bank.

- Wei, Shang-Jin. 2000. "How taxing is corruption on international investors?." Review of economics and statistics 82, no. 1: 1-11. 
EUROPOLITY, vol. 12, no. 2, 2018 